\title{
ECONOMIC INTEGRATION, POLITICAL INTEGRATION OR BOTH?
}

\author{
Daniel Brou \\ The University of Western Ontario \\ Michele Ruta \\ World Trade Organization
}

21 March 2010

\begin{abstract}
We study the effects of economic and political integration by presenting a model in which firms compete with each other in both an economic market - where they produce a good and compete for market share - and in a political (rent seeking) market - where they compete for transfers from the government. Growth is driven by firms' cost-reducing innovation activity and economic and political integration affect firms' incentive to innovate differently. In this setting, economic and political integration can be seen as complementary. Economic integration, when not accompanied by political integration, can lead to less innovation and slower growth as firms respond to increased competition in the economic market by focusing more on rent seeking activity. When economic integration is accompanied by political integration, innovation and growth will be stronger and welfare higher.(JEL: D72, F15, F55, O31)
\end{abstract}

\section{Introduction}

Political borders are fluid. Since the end of World War II, we have observed an impressive incidence of political disintegration. Indeed, the number of independent countries is now almost three times greater than it was in 1945. On the other hand, there are also examples of the opposite process. International political (along with economic) integration has occurred in Europe, where nation states

The editor in charge of this paper was George-Marios Angeletos.

Acknowledgments: We thank Carlotta Berti Ceroni, Alessandra Casella, Ronald Findlay, Louis Hotte, Omar Licandro, Massimo Morelli, Brendan O’Flaherty, Pablo Pinto, Lant Pritchett, Susan RoseAckerman, Frances Rosenbluth, Uwe Sunde and Jaume Ventura for helpful discussions. Comments from seminar participants at the WTO, Yale University, Universitat Pompeu Fabra, European University Institute, Third Annual Conference of the Euro-Latin Study Network on Integration and Trade (ELSNIT) in Kiel, IV Workshop on Dynamic Macroeconomics in Bologna, the Meetings of the Canadian Economic Association in Montreal and the European Economic Association in Vienna are gratefully acknowledged. Special thanks to George-Marios Angeletos (the Editor) and two anonymous referees for very helpful suggestions. Michele Ruta thanks the Leitner Program in International Political Economy at Yale University for hospitality. Disclaimer: The opinions expressed in this paper should be attributed to the authors. They are not meant to represent the positions or opinions of the WTO and its Members and are without prejudice to Members' rights and obligations under the WTO.

Email addresses: dbrou@uwo.ca (Brou; michele.ruta@wto.org (Ruta) 


\section{Forthcoming in the Journal of the European Economic Association}

Brou and Ruta Economic integration, political integration or both?

have imposed limits on their sovereign use of certain policies (e.g. fiscal policy), have delegated control over some relevant competencies, such as trade policy and antitrust, to the European Union and are debating further political integration.

While economists have generally devoted their attention to the growth effects of economic integration, the consequences of political integration on economic growth have received surprisingly little attention. ${ }^{1}$ Does political integration affect economic growth? And if so, through what channels? Perhaps more importantly, is political integration beneficial for growth (and separatism harmful) as economic markets globalize?

The main result of our analysis is that political and economic integration can be complementary. This result is contrary to the previous literature which treats political integration as a way of expanding economic markets when the option of economic integration is not available. By contrast we conclude that, when firms participate in both the economic and political markets, political integration prevents economic integration from skewing firms' incentives away from productive activity and toward rent seeking.

We study integration in a framework where growth is endogenous and depends on how much firms invest in research and development (R\&D). Firms choose to devote resources to both productive activities (production of final goods and $R \& D$ ) and to an unproductive activity. ${ }^{2}$ In particular, unproductive activity takes the form of a competition for the distribution of government transfers - that is, a game of rent seeking. Since firms participate in both an economic market - where they compete for market share - and in a political market - where they compete for transfers from the government - changes in one market will have an impact on behavior in the other. This is the channel we isolate to study the effects of economic and political integration. We argue that, other things equal, political integration changes the level of competition within the political market and has consequences for innovation and growth. Consider political disintegration: when a country breaks up, some regions become newly independent political entities. Regional governments assume new prerogatives and decide aspects of economic policy that were formerly the domain of a central government. Firms in a newly independent region, formerly seeking rents from the central authority, must now influence the local government. The number of firms vying for rents in the political market of the newly independent political entity can be affected. Importantly, this effect carries through to the economic market since it has an effect on firms'

\footnotetext{
1. An important exception is the work by Alesina, Spolaore and Warcziarg (2000 and 2005) and Spolaore and Warcziarg (2005), which will be discussed below.

2. We define unproductive activity similarly to Bhagwati (1982) whose directly unproductive profitseeking (DUP) activities are "ways of making profits (i.e. income) by undertaking activities that are directly unproductive, in the sense that they produce pecuniary returns but do not produce goods or services that enter a conventional utility function or input into such good and services."
} 


\section{Forthcoming in the Journal of the European Economic Association}

gross profits and the number of firms that can be supported in equilibrium.

We assume an oligopolistic goods market with an endogenous number of firms engaging in the production of a differentiated final good and undertaking two main activities other than final good production: in-house R\&D (innovation) and rent seeking. Both activities can be profitable for firms, but have very different consequences for the welfare of society. Rent seeking requires a firm to devote scarce resources (in the form of labor) to obtaining transfers from the government. In this sense rent seeking is purely wasteful, while industrial $R \& D$ generates knowledge that reduces firm-specific costs and can be used in subsequent R\&D activity, thus increasing the growth rate of the economy. With free entry, the number of firms in each region is determined by the zero profit condition that firms' cash flows just cover their fixed, R\&D and rent seeking costs. Among other measures of competitiveness, the number of firms interacting in the economic and political markets plays a role in determining firms' incentives to engage in $R \& D$, which drives economic growth.

The economic model builds on the work of Peretto (1996 and 2003). This approach allows us to study the effects of integration on competition, $R \& D$, growth and welfare among global oligopolists who interact strategically. These issues are complex by nature, but - under the assumption of symmetry - the model yields tractable results. It also incorporates the desirable features that openness to foreign competition drives domestic firms out of business and it includes R\&D spillovers without implying unrealistic scale effects.

Political integration makes the competition for transfers more intense. Firms must increase their rent seeking effort in order to maintain their share of government transfers. As profits from the political market fall, each firm must rely more on the economic market for profits. This makes competition in the economic market more intense and increases the incentive to innovate. At the same time, higher costs of rent seeking drive some local firms out of the market. This has the effect of reducing the number of firms competing in the economic market, which reduces the incentive to innovate. Overall, the effect of political integration on innovation, growth and welfare is ambiguous.

Economic integration, by making the economic market more competitive, increases firms' incentive to innovate in order to lower costs and capture a greater share of the market. A resulting higher cost of innovation leads to the exit of some local firms. In the absence of political integration, this has the effect of making rent seeking more attractive because there are less firms competing for distribution from the local government. Greater profits from the political market reduce a firm's need to compete in the economic market and reduce the incentive to innovate. The overall effect of economic integration on innovation, growth and welfare is ambiguous.

Notice that political and economic integration have similar implications. Integration in one market has a positive effect on innovation and growth by making 


\section{Forthcoming in the Journal of the European Economic Association}

that market more competitive, but decreases the number of firms in the other market. Political integration alone cannot guarantee improvements in growth or welfare and neither can economic integration on its own. We then show that joint economic and political integration improve economic performance by ensuring that competition increases in both markets. Firms have a greater incentive to invest in $R \& D$ in order to keep their market share and the incentive to focus on rent seeking activities is muted. We conclude that political and economic integration are complementary institutions.

The idea that political integration creates competition between different rent seekers has been formalized by Olson (1982) and Buchanan (1990), but has a rich intellectual history which includes Hume (1987), Madison (1788) and Spinelli (1957). Though there is little direct evidence on the effect of political integration on unproductive political activity, Persson, Tabellini and Trebbi (2003) show that larger political districts lead to lower measures of corruption. The link between rent seeking and economic growth has been established by Baumol (1990), who argues that growth depends on the allocation of resources between productive activities, such as innovation, and unproductive ones, such as rent seeking and organized crime. ${ }^{3}$ In a framework similar to the one employed in this paper, Brou and Ruta (2008) show how rent seeking affects economic growth (i.e. by altering incentives to devote resources to innovation and through its effects on the structure of markets) and study how different specifications of the rent seeking game alter the growth effects of firms' unproductive activities. Differently from these works, we study how political and economic integration influence firms' incentives to engage in $R \& D$ relative to rent seeking.

A recent, but growing, literature studies the economic determinants and the effects on welfare of the break up and unification of countries. ${ }^{4}$ The main channel through which political integration affects economic growth in this literature is through its effect on the size of the economic market. Alesina, Spolaore and Wacziarg (2000 and 2005) and Spolaore and Wacziarg (2005) argue that, in a world with important trade restrictions, political integration has a positive effect on economic growth because it increases the size of the economic market. On the other hand, in a regime of free trade, political integration should not matter for economic growth since the size of the economic market is independent of political borders. Their empirical analysis confirms that the effects of country size on growth are less important as economies become more open. In this approach,

3. A similar argument is developed within an endogenous growth model by Murphy, Shleifer and Vishny (1991), who also find some empirical support in a cross country analysis.

4. One branch of this literature deals with mostly static concerns and frames the political integration decision as a trade-off between the benefits arising from economies of scale in public good provision and the internalization of cross-border externalities and the costs arising from a loss of sovereignty or a change in the political equilibrium. See Alesina and Spolaore (2003) and Ruta (2005), as well as the work referenced therein for details. 


\section{Forthcoming in the Journal of the European Economic Association}

Brou and Ruta Economic integration, political integration or both?

political and economic integration are both seen as ways to increase market size and, as a result, are substitutes. Our work differs in that we consider the two types of integration as inherently different processes with different implications for economic behaviour - in particular the incentives of firms to innovate. ${ }^{5}$

The literature on the effects of economic integration on growth is extensive and we do not attempt to summarize it here. Our work is most closely related to the literature on how economic integration affects the level of competition in a market, which in turn affects firms' incentive to innovate. As discussed earlier, our approach is highly indebted to the work of Peretto (2003) who builds on Grossman and Helpman (1991) and studies the effects of economic integration on market structure and economic growth. Similarly to other work in this area (e.g. Aghion and Howitt, 1998), economic integration has a positive effect on growth by increasing competition in economic markets. ${ }^{6}$ We contribute to this line of research by introducing a political market, allowing us to consider both economic and political integration. In a similar spirit, Giovazzi and Tabellini (2005) study the empirical relationship between economic and political liberalizations. The focus is on democratization rather than political integration, but their results support the idea that the effect of economic and political liberalizations on growth is not additive. Countries that enact both reforms have better economic performance than those that enacted only one kind of reform.

The paper is organized as follows. The following Section presents the formal model. We describe a typical firm's optimal behavior in Section 3 and solve for the general equilibrium of the economy in Section 4. Section 5 studies political and economic integration. We discuss conclusions and applications in Section 6.

\section{The model}

Consider an economy composed of $m$ regions. Each region has a population of identical individuals of size $L$. Consumers have symmetric preferences over differentiated goods supplied by oligopolistic producers and are endowed with

\footnotetext{
5. The empirical result of Alesina, Spolaore and Wacziarg (2005) is not a contradiction to our analysis exactly because they measure political integration by county size (population). But this is not a perfect measure of competition in the political market - just like market size is not an adequate measure of competition in the economic market.

6. Early empirical work in industrial organization (e.g. Nickell, 1996, Blundell et al., 1995) found a positive relationship between product market competition (measured by, among other things, the number of competitors in the same industry) and productivity growth within a firm or industry. More recent analysis (Aghion et al., 2005) finds that the relationship between innovation and competition is more properly characterized by an inverted-U shape -that is, an increasing number of competitors leads to productivity growth only up to a certain point. While we do not attempt to formalize this nonmonotonicity, our results are contingent on being on the positive side of this empirical relationship (i.e. where the number of firms is not too large).
} 


\section{Forthcoming in the Journal of the European Economic Association}

Brou and Ruta Economic integration, political integration or both?

one unit of labor each. We abstract from the labor-leisure decision, so that total labor supply in each region is $L$. In region $k$, there are $n_{k}$ endogenously determined firms. Firms interact in two different markets. In the economic market, firms engage in the production of a good that is demanded by consumers and in $R \& D$ activities aimed at lowering the cost of production. In the political market, firms devote valuable resources, in the form of labour, to rent seeking activities. Regions can be integrated into a single political entity (a political union) and a single market (economic union) or disintegrated into different independent states and separate economies. Economic integration implies that all firms sell their product to all consumers in the union. The number of regions in an economic union is denoted $m_{e}$. Political integration means that a supranational government taxes all citizens in order to finance its expenditures. Firms seeking redistribution must deal with this level of government. The number of regions in a political union is denoted $m_{p}$.

\subsection{The economic market}

The economic market is modeled following Peretto (2003). In the economic market, firms compete with each other for market share. We assume an oligopolistic market in differentiated goods where consumers have love-of-variety preferences. Firms compete by setting prices and investing in cost reducing R\&D. There are a total of $M_{e}=\sum_{k=1}^{m_{e}} n_{k}$ firms each producing a different product in the economic market. Consumers in the economic union have access to all $M_{e}$ goods produced in the union.

2.1.1. Demand. Each firm's demand is derived from the optimizing behavior of consumers. Recall that in each region there are $L$ identical individuals with symmetric preferences across all goods. Given the number of regions, $m_{e}$, in the economic union, an individual living in region $k$ maximizes lifetime utility

$$
U_{k}(t)=\int_{t}^{\infty} e^{-\rho(\tau-t)} \log C_{k}(\tau) d \tau
$$

subject to the intertemporal budget constraint that the present discounted value of expenditure cannot be greater than the present discounted value of income plus initial wealth:

$$
\int_{t}^{\infty} R(\tau)\left[E_{k}(\tau)+T_{k}(\tau)\right] d \tau \leq \int_{t}^{\infty} R(\tau)[W(\tau)+D(\tau)] d \tau+A_{k}(t),
$$

where $\rho>0$ is the individual discount rate, $R(\tau)$ is the cumulative discount factor from time $t$ to time $\tau, E_{k}=\sum_{i=1}^{n_{k}} p_{i k} C_{i k}+\sum_{s \neq k}^{m_{e}} \sum_{i=1}^{n_{s}} p_{i s} C_{i s}$ is per capita expenditure on all consumption goods, and $T_{k}$ is the constant lump-sum per capita tax in region $k$. $W \equiv 1$ is the wage rate, which we take as the numeraire. Finally, $A_{k}$ is per capita 


\section{Forthcoming in the Journal of the European Economic Association}

Brou and Ruta Economic integration, political integration or both?

asset holdings in region $k$ and $D$ represents dividend income. ${ }^{7}$ The consumption index $C_{k}$ is given by ${ }^{8}$

$$
C_{k}=\left[\sum_{i=1}^{n_{k}} C_{i k}^{\frac{\varepsilon-1}{\varepsilon}}+\sum_{s \neq k}^{m_{e}} \sum_{i=1}^{n_{s}} C_{i s}^{\frac{\varepsilon-1}{\varepsilon}}\right]^{\frac{\varepsilon}{\varepsilon-1}},
$$

where $\varepsilon>1$ is the elasticity of product substitution, $C_{i k}$ is consumption of good $i$ produced in region $k$ and $C_{i s}$ is consumption of good $i$ produced in region $s$. Lastly, $n_{k}$ and $n_{s}$ are the number of goods produced in region $k$ and region $s$, respectively.

In order to simplify notation, we introduce the following price index for region $k$ :

$$
p_{k}=\left[\sum_{i=1}^{n_{k}} p_{i k}^{1-\varepsilon}+\sum_{s \neq k}^{m_{e}} \sum_{i=1}^{n_{s}} p_{i s}^{1-\varepsilon}\right]^{\frac{1}{1-\varepsilon}},
$$

where $p_{i k}$ and $p_{i s}$ are the prices of good $i$ in region $k$ and $s$, respectively.

In this standard framework, households obtain the optimal expenditure plan by setting

$$
\frac{\dot{E}_{k}}{E_{k}}=r-\rho
$$

and, given this time path for expenditures, maximizing (2) subject to $E$. This yields the demand for consumption of good $i$ produced in region $k$ by a consumer located in region $l, C_{i k}^{l}=E_{k}\left(p_{i k}^{1-\varepsilon} / p_{s}^{1-\varepsilon}\right)$. Using these individual demand curves, total demand faced by firm $i$ from region $k$ is

$$
X_{i k}=\frac{L E_{k}}{p_{i k}} \frac{p_{i k}^{1-\varepsilon}}{p_{k}^{1-\varepsilon}}+\sum_{s \neq k}^{m_{e}} \frac{L E_{s}}{p_{i k}} \frac{p_{i k}^{1-\varepsilon}}{p_{s}^{1-\varepsilon}} \equiv S_{i k}^{k} \frac{L E_{k}}{p_{i k}}+\sum_{s \neq k}^{m_{e}} S_{i k}^{s} \frac{L E_{s}}{p_{i k}},
$$

where $S_{i k}^{s} \equiv p_{i k}^{1-\varepsilon} / p_{s}^{1-\varepsilon}$ is the the share of country $s$ 's market captured by firm $i$ from region $k$ and $p_{s}$ is the price index of consumption goods in region $s$.

\subsubsection{Production technology. Each firm produces output with technology}

$$
X_{i k}=Z_{i k}^{\theta}\left(L_{x_{i k}}-\varphi\right),
$$

where $X_{i k}$ is the output of firm $i$ in region $k$ and $L_{x_{i k}}$ is labor used in production, while $\varphi>0$ is a fixed and sunk cost of production that the firm has to pay in

7. In free entry/exit equilibrium, profits will always be zero implying that this term can be omitted without loss of generality.

8. Unless there is possibility of confusion, in the rest of the article we omit time subscripts for ease of exposition. 


\section{Forthcoming in the Journal of the European Economic Association}

each period of activity. The firm's knowledge (or patent) stock is given by $Z_{i k}$ and $\theta \in(0,1)$ is the elasticity of cost reduction.

Firms invest in R\&D in order to accumulate cost reducing innovations that are patented. Since $\theta \in(0,1)$, labor productivity increases with the patent stock. Technological innovation evolves according to the following condition

$$
\dot{Z}_{i k}=L_{z_{i k}}\left[Z_{i k}+\sum_{j \neq i}^{n_{k}} \frac{\gamma}{1+\delta\left(n_{k}-1\right)} Z_{j k}+\sum_{s \neq k}^{m_{e}} \sum_{j=1}^{n_{s}} \frac{\gamma}{1+\delta\left(n_{s}-1\right)} Z_{j s}\right] \equiv L_{z i k} K_{i k} .
$$

The innovation technology represented by equations (5) and (6) implies that individual firms use their own, proprietary knowledge in producing output, but all firms benefit from the R\&D of other firms in the economic market. We assume that technological spillovers are transmitted through trade so that the relevant knowledge base depends on the level of economic integration. The parameter $\gamma \in[0,1]$ determines the share of privately developed $R \& D$ that becomes publicly available. The parameter $\delta$ determines how quickly congestion sets in. If the firm allocates $L_{z_{i k}}$ units of labor to R\&D in an interval of time $d t$, it produces $\dot{Z}_{i k}$ new patents. Following Peretto (2003), we assume that firms take the total stock of knowledge $\left(K_{i k}\right)$ as given.

Profits from the economic market can be expressed as

$$
\Pi_{i k}^{e}=p_{i k} X_{i k}-L_{x_{i k}}-L_{z_{i k}} .
$$

An important measure of market competition is the number of regions in the economic union, $m_{e}$. We can refer to this exogenous parameter as the level of foreign competition. ${ }^{9}$ But the total number of firms also depends on the endogenous number of firms in each region, $n_{k}$, which - in our symmetric set up - measures both concentration and (the inverse of) average firm size. The total number of firms competing for market share - and the total number of goods available to consumers - is $M_{e}$.

\subsection{The political market}

The political market is modeled as a simple contest for redistribution in the spirit of Tullock (1980). Firms must expend real resources in order to obtain a share of the fiscal pie. The share that each firm receives is an increasing function of that firm's share in total rent seeking activity. Firms compete by choosing the

9. There are other exogenous measures of competition. The elasticity of product substitution, $\varepsilon$, measures how easily consumers substitute between product varieties while the elasticity of cost reduction, $\theta$, measures how sensitive a firm's costs are to new cost reducing innovations. Higher levels of $\varepsilon$ and $\theta$ imply more highly contested economic markets. Following the terminology of Bliss and Di Tella (1997), we can refer to these as deep parameters of competition. 


\section{Forthcoming in the Journal of the European Economic Association}

amount of labor to dedicate toward rent seeking activity. There are a total of $M_{p}=\sum_{k=1}^{m_{p}} n_{k}$ firms each vying for redistribution from the government. The government finances these transfers by imposing a lump-sum tax on consumers.

2.2.1. Rent seeking technology. We use a general version of the rent seeking contest described by Tullock. In this set up, given the number of regions in the political union $\left(m_{p}\right)$, the government has a fixed budget, $B\left(m_{p}\right)$, which is to be distributed among the contestants. Each firm receives a fraction of the budget proportional to its share in total rent seeking activity. We allow only firms that are active in the economic market to compete for government transfers. In each period, the government responds to firms' rent seeking activity according to the following technology,

$$
Q_{i k}=\left[\frac{L_{Q_{i k}}^{v}}{\sum_{k=1}^{m_{p}} \sum_{i=1}^{n_{s}} L_{Q_{i k}}^{v}}\right] B\left(m_{p}\right),
$$

where $Q_{i k}$ denotes the rents transferred to firm $i$ in region $k, L_{Q_{i k}}$ is labor used in rent seeking by firm $i$ in region $k$, and $v \in\left(0, M_{p} /\left(M_{p}-1\right)\right)$ measures the responsiveness of government to rent seeking effort. ${ }^{10}$ Notice that an increase in the government's responsiveness increases the effectiveness of a firm's own effort in obtaining transfers. But it also increases the effectiveness of the effort of other firms which, since this is a game of distribution, has a negative impact on each firm's ability to obtain transfers. This simple technology is consistent with two aspects of rent seeking that are widely described in the literature. First, rent seeking is a directly unproductive activity in that firms dedicate real resources to obtain a profit without producing any good or service (along the lines of Baghwati, 1982). Secondly, competition between different special interests reduces the returns to rent seeking (along the lines of Becker, 1983). ${ }^{11}$

Profits from the political market can be expressed as

$$
\Pi_{i k}^{p}=Q_{i k}-L_{Q_{i k}}
$$

10. In Tullock (1980), the parameter $v$ is equal to unity. The restriction on $v$ requires a brief explanation. Whenever $v>M_{p} /\left(M_{p}-1\right)$, two problems arise. First, in the symmetric Tullock game there will be a continuum of (payoff equivalent) asymmetric mixed strategy equilibria along with the unique symmetric equilibrium. Second, there will be full rent dissipation - firms will not profit from rent seeking activity. Since the asymmetric equilibria guarantee contestants the same payoff and we want focus on the more interesting case where rent seeking can be profitable for firms, the restriction is imposed. See Baye, Kovenock and DeVries (1999) for a more detailed discussion of these issues.

11. More generally, this reduced-form model can be interpreted as capturing the welfare reducing activities of interest groups (e.g. lobbying for subsidies). To the extent that these activities distort economic activity, they reduce welfare. Some limitations to this interpretation are discussed in the conclusion of this paper. 


\section{Forthcoming in the Journal of the European Economic Association}

The government must balance its budget in each period by collecting lumpsum taxes, $T_{k}$, in order to finance transfers to firms. The budget constraint is given by

$$
B=m_{p} L T_{k}=\sum_{k=1}^{m_{p}} \sum_{i=1}^{n_{s}} Q_{i k}
$$

Notice that political integration (i.e. an exogenous increase in $m_{p}$ ) implies an equi-proportional increase in the number of firms vying for rents and in the size of the budget over which they compete. We assume the tax rate is fixed and exogenous so that $T_{k}$ is not affected by integration. The level of foreign competition in the political market is given by $m_{p}$, the number of regions in the political union. Again, market structure is summarized by the (endogenous) number of firms that operate in each region, $n_{k}$. The total number of firms competing for redistribution is $M_{p} .{ }^{12}$

Our choice of this model is motivated by its ability to parsimoniously introduce oligopoly consideration, $R \& D$, rent seeking and allow for a closed form solution in a general equilibrium framework with endogenous growth. In particular, our focus is on capturing the effects of integration on economic growth through industrial restructuring. On the economic side, the assumption of a differentiated oligopoly market captures the idea that a greater variety of firms results in greater (price) competition. Cost reducing technological innovation with spillovers provides a further channel through which competition drives growth. On the political side, greater competition reduces the profitability of rent seeking. In this set up, economic integration gives consumers and producers access to foreign goods and knowledge, generating a more competitive market where firms have access to more technology and can support faster economic growth. ${ }^{13}$ Economic integration will also affect the level of competition in the political market as it alters the number of domestic firms that survive. It is this interaction between political and economic markets, through market structure that will be the focus of our analysis.

12. As with the economic market, there are other measures of competition in the political market. The responsiveness of government to rent seeking effort, $v$, measures how sensitive transfers are to differences in rent seeking effort. When $v$ is high, small differences in rent seeking effort can lead to large differences in transfers received by firms. Thus $v$ is a deep parameter of competition in the political market.

13. Spillovers are not necessary in obtaining our key results, but their presence is a realistic feature of the model and reinforces the results without complicating exposition. Empirically, the importance of R\&D spillovers in international integration has been established by Coe and Helpman (1995) and Lumenga-Neso, Olearraga and Schiff (2005), among others. Allowing for spillovers does ensure that our results continue to hold in the limit case, where the number of firms becomes very large. 


\section{Forthcoming in the Journal of the European Economic Association}

\section{Firm behavior}

Following Peretto (2003) we give an informal description of the Nash equilibrium in the manufacturing sector. Firms choose time paths of price, R\&D spending and rent seeking expenditure in order to maximize the present discounted value of net cash flow. For firm $i$ in region $k$, the present discounted value of net cash flows is

$$
V_{i k}(t)=\int_{t}^{\infty} R(\tau) \Pi_{i k}(\tau) d \tau,
$$

where instantaneous profits are given by

$$
\Pi_{i k}=\Pi_{i k}^{e}+\Pi_{i k}^{p}=p_{i k} X_{i k}+Q_{i k}-L_{x_{i k}}-L_{z_{i k}}-L_{Q_{i k}} .
$$

The firm will maximize $V$ subject to technological constraints (5) and (6), the political constraint (8) and total demand (4), while taking as given the number of active firms and its competitors' pricing, innovation and rent seeking strategies. We assume that the initial knowledge is given and equal for all firms in all regions. A full derivation of the firm's optimal behavior is provided in the Technical Appendix.

\subsection{The economic market}

Each firm sets its price according to the optimal Bertrand-Nash price strategy $p_{i k}=\left[\xi_{i k} /\left(\xi_{i k}-1\right)\right] Z_{i k}^{-\theta}$, where $\xi_{i k}$ is the price elasticity of demand faced by the firm. The rate of return on innovation is given by

$$
r=\frac{\theta\left(\xi_{i k}-1\right)}{\xi_{i k}}\left[S_{i k}^{k} L E_{k}+\sum_{s \neq k}^{m_{e}} S_{i k}^{s} L E_{s}\right] \frac{K_{i k}}{Z_{i k}}-\frac{\dot{K}_{i k}}{K_{i k}} .
$$

In the symmetric equilibrium, the pricing strategy is given by (removing all subscripts to denote the symmetric equilibrium values)

$$
p_{i k} \equiv p=\frac{\xi}{\xi-1} Z^{-\theta}, \forall i, k
$$

where $\xi=\varepsilon-(\varepsilon-1) / m_{e} n$. The rate of return on innovation allows us to solve for the optimal R\&D strategy:

$$
L_{z_{i k}} \equiv L_{z}=\frac{L E \theta(\xi-1)}{n \xi}-\frac{r}{\alpha}, \forall i, k,
$$

where $\alpha \equiv 1+\left[\gamma\left(m_{e} n-1\right) /\left(1+\delta\left(m_{e} n-1\right)\right)\right]$ represents the productivity of labor in R\&D. 


\section{Forthcoming in the Journal of the European Economic Association}

Brou and Ruta Economic integration, political integration or both?

Equation (14) defines each firm's R\&D effort in partial equilibrium. It is useful to consider the determinants of this R\&D strategy. The term $L E / n \xi$ represents the gross-profit effect that depends on total sales per firm $L E / n$ and the mark-up $1 / \xi$. The term $\theta(\xi-1)$ is the business-stealing effect - by investing in cost reducing innovations, firms lower prices and expand their market share. An increase in foreign competition $\left(m_{e}\right)$ is associated with an increase in R\&D effort. As the economic market becomes more competitive, firms have more to gain by cutting costs. At the same time, equation (13) shows that the firm must charge a lower price when $m_{e}$ is high. Similarly, a higher $m_{e}$ increases technological spillovers and makes innovation less costly. But it does so for all competitors. In Nash equilibrium this results in greater expenditures on $R \& D$, as can be seen by the term $-r / \alpha$. Using these two conditions, we can rewrite profits from the economic market as

$$
\Pi^{e}=p X-L_{x}-L_{z}=\frac{L E\left[1-\theta\left(\xi\left(M_{e}\right)-1\right)\right]}{n \xi\left(M_{e}\right)}+\frac{r}{\alpha\left(M_{e}\right)}-\varphi,
$$

where the notation makes explicit that the elasticity of demand depends on the total number of firms in the economic market $\left(M_{e}\right)$. Notice that an increase in the deep parameters of competition ( $\varepsilon$ and $\theta$ ) and/or in the level of foreign competition $\left(m_{e}\right)$ reduces profits from the economic market for a given $n$.

\subsection{The political market}

At each point in time, firms set their rent seeking strategy in response to their competitors' behavior according to

$$
L_{Q_{i k}}=v B \mathscr{S}_{i k}^{p}\left(1-\mathscr{S}_{i k}^{p}\right)
$$

where $\mathscr{S}_{i k}^{p}$ is the share of effective rent seeking effort by firm $i$ in region $k$ and is defined as

$$
\mathscr{S}_{i k}^{p} \equiv \frac{L_{Q_{i k}}^{v}}{\sum_{k=1}^{m_{p}} \sum_{i=1}^{n_{s}} L_{Q_{i k}}^{v}}
$$

In symmetric equilibrium, $\mathscr{S}_{i k}^{p} \equiv \mathscr{S}^{p}=1 / m_{p} n$ and we can rewrite profits from the political market as

$$
\Pi^{p}=Q-L_{Q}=\frac{B\left[1-v\left(1-\mathscr{S}^{p}\right)\right]}{m_{p} n}=\frac{L T\left[1-v\left(1-\mathscr{S}^{p}\left(M_{p}\right)\right)\right]}{n}
$$

where the last equality uses the government budget constraint (10) and the notation makes explicit that the share of effective rent seeking $\left(\mathscr{S}^{p}\right)$ depends on the total number of firms in the political market $\left(M_{p}\right)$. Notice that an increase in the deep competition parameter $(v)$ or an increase in foreign competition $\left(m_{p}\right)$ results in greater rent seeking effort and lower profits from the political market. 


\section{Forthcoming in the Journal of the European Economic Association}

\section{Market structure and growth}

Market structure plays an important role in the general equilibrium of this economy. Given the firm behavior described in the previous Section, entry/exit decisions will determine the number of active firms. Market clearing conditions are then imposed in order to determine the general equilibrium of the economy.

\subsection{Equilibrium market structure}

We assume that the cost of entry is zero. In an equilibrium with free entry, total profits, $\Pi_{i k}$, must equal zero at all time. Imposing symmetry, we have $\Pi_{i k}=\Pi$ for all $i$ and $k$. Using equations (11), (15), and (17), the zero-profit condition can be written as

$$
\frac{L E[1-\theta(\xi-1)]}{n \xi}+\frac{r}{\alpha}+\frac{L T\left[1-v\left(1-\mathscr{S}^{p}\right)\right]}{n}=\varphi .
$$

The zero profit condition demonstrates the interaction between the level of competition in the two markets. Consider a change in one of the deep parameters of economic competition. An increase in $\varepsilon$, for example, results in an increase in competition in the economic market as consumers find it more palatable to substitute between different varieties. Each firm has less market power, is forced to charge a lower markup and needs to invest more in cost reducing R\&D. Profits from the economic market decrease, but the zero profit condition ensures that this decrease in profitability leads to the exit of some firms. As $n$ decreases, there is less competition between firms also in the political market leading to an increase in rent seeking activity and political profits.

We now turn our attention to obtaining an expression for equilibrium expenditures. From condition (11), the zero profit condition can be rewritten as $p_{i k} X_{i k}+Q_{i k}=L_{x i k}+L_{z i k}+L_{Q i k}$. Summing across firms and imposing the labor market clearing condition in region $k$, yields

$$
L=\sum_{i=1}^{n_{k}}\left(L_{x i k}+L_{z i k}+L_{Q i k}\right)=\sum_{i=1}^{n_{k}}\left(p_{i k} X_{i k}+Q_{i k}\right) .
$$

Imposing symmetry, we have per capita expenditures

$$
E=1-\frac{n Q}{L}=1-T,
$$

where the last equality relies on the fact that in symmetric equilibrium, the government's budget constraint is $m_{p} L T=m_{p} n Q$. Notice that taxes (which are used 


\section{Forthcoming in the Journal of the European Economic Association}

to distribute rents to firms) reduce per capita equilibrium expenditures. ${ }^{14}$ Moreover, note that $E$ is constant over time. Jointly with condition (3), this implies that $r=\rho$ in equilibrium.

We can now write the zero profit condition as

$$
\frac{L[1-T]\left[1-\theta\left(\xi\left(m_{e} n\right)-1\right)\right]}{n \xi\left(m_{e} n\right)}+\frac{\rho}{\alpha\left(m_{e} n\right)}+\frac{L T\left[1-v\left(1-\mathscr{S}^{p}\left(m_{p} n\right)\right)\right]}{n}=\varphi .
$$

The market structure of this economy depends on the interaction of firms in the economic and political markets. The price elasticity of demand $\xi\left(m_{e} n\right)$ and the share of effective rent seeking $\mathscr{S}^{p}\left(m_{p} n\right)$ are expressed as functions of the number of firms in order to highlight the role of economic and political integration in determining firm profits. This condition implicitly determines the equilibrium number of firms in each region, $n$. The left-hand side of equation (20) is everywhere decreasing in $n$, thus implying that the equilibrium exists and is unique. This relationship is depicted in Figure 1, with the curve representing the left-hand side labeled $\Pi-\varphi$. Changes in market structure will occur whenever something alters the relationship between $\Pi-\varphi$ and $n$, causing a shift in the curve.

[FIGURE 1 APPROXIMATELY HERE]

\subsection{Equilibrium growth and welfare}

Along the balanced growth path, both consumer expenditures and the number of firms are constant. The rate of cost reduction then determines the growth of output and consumption. We can define this as $g \equiv \dot{C} / C=\theta \dot{Z} / Z=\theta \alpha L_{z}$.

From condition (14), we have the firm's R\&D strategy as a function of total expenditures. Firms take the number of competitors in the economic and political market as given and choose the optimal level of R\&D using equation (14). The equilibrium number of firms, in turn, is endogenous and determined by the zero profit condition. Substituting the zero profit condition (20) into the last equation and using the definition of growth yields the equilibrium growth rate of the economy

$$
g(n)=\theta \frac{\theta \alpha\left(m_{e} n\right)\left[\xi\left(m_{e} n\right)-1\right]\left[\varphi-\Pi^{p}\left(m_{p} n\right)\right]-\rho}{1-\theta\left[\xi\left(m_{e} n\right)-1\right]} .
$$

This condition is a modified version of the firm's $R \& D$ decision which takes into account that firms have perfect foresight and correctly perceive the effect of

14. None of the results to follow would be altered if it were firms rather than consumers who paid the tax. The only difference would be that, in symmetric equilibrium, the amount of taxes paid by each firm would exactly equal the transfers received and $\Pi^{p}=-L_{Q}$. All other results and comparative statics would be the same. We prefer the assumption that taxes are paid by consumers because firms extract some benefit from rent seeking. 


\section{Forthcoming in the Journal of the European Economic Association}

parameter changes on their profits and, based on this, choose whether to be active or not. Rent seeking has an important impact on the incentive for firms to invest in $R \& D$ and therefore on growth. The higher are profits from the political market, the less important is the economic market for each firm's survival. Profits from rent seeking provide firms with a certain amount of "slack" in economic competition. The equilibrium number of active firms determines competition in the economic and political markets, $R \& D$, pricing and rent seeking strategies and, ultimately, long run growth. This relationship is depicted in Figure 2. Equilibrium growth is determined by the growth schedule (21) together with the equilibrium number of firms as determined by the zero profit condition (20). Changes in the equilibrium growth rate will come about as a result of shifts in the growth schedule and/or changes in regional market structure.

[FIGURE 2 APPROXIMATELY HERE]

Welfare for the typical consumer is given by

$$
U=\frac{1}{\rho}\left[\frac{1}{\varepsilon-1} \log \left(m_{e} n\right)+\log \frac{\xi\left(m_{e} n\right)-1}{\xi\left(m_{e} n\right)}+\frac{g}{\rho}+\log (1-T)\right] .
$$

The first two terms capture the fact that consumers benefit from increases in the number of consumption goods and the quantity of each good that they consume. The third term captures the fact that utility is also increasing in the growth rate of the economy, which is also the growth rate of consumption. The final term recognizes that, in general equilibrium, redistributive taxation leads to a deterioration in expenditures. Economic and political integration will play a role in determining both the number of varieties available to consumers as well as the growth rate of the economy by altering the incentives of firms to devote resources to cost reducing $\mathrm{R} \& \mathrm{D}$.

\section{The effects of integration}

We begin by studying the results of political and economic integration separately. Later, we will study the consequences of joint economic and political integration.

We provide the following definitions of what we mean by political and economic integration.

- Political integration is captured by an increase in $m_{p}$. This exogenous increase in the size of the political market allows firms to seek rents from a larger pool of resources (the tax revenue of the larger political union). At the same time, firms will have to compete for rents with firms in more regions.

- Economic integration is captured by an increase in $m_{e}$. This exogenous increase in the size of the economic market allows firms to sell their products to more consumers in more regions with no limits (quotas, tariffs, etc.) At the 


\section{Forthcoming in the Journal of the European Economic Association}

same time, firms will have to compete for market share with firms in more regions.

Our definition of political integration is admittedly restrictive along several dimensions (see also the discussion of this point in Section 6), however it allows us to focus on the implications that a larger political market has for rent seeking and its effect -through this channel- on economic growth and welfare. Underlying this definition there are two simplifying assumptions that require further discussion. First, in the absence of political integration, a firm in region $s$ cannot obtain transfers from the government of region $s^{\prime}$. The assumption here is that only members of the polity are eligible for transfers from the government. ${ }^{15}$ Second, one could argue that political integration may lead to a change in the size of the "political pie" that rent seekers can distort to their advantage (i.e. a variation in the $\operatorname{tax} T$ ) or in the rent seeking technology (i.e. a variation in the responsiveness of the government $v$ ). The direction of change, however, is not $a$ priori clear and in the ensuing discussion we abstract from it.

Economic integration is interpreted as an exogenous move from autarky to free trade. However, our results would not change if we were to introduce in the model trade restrictions between regions (e.g. tariffs) and define economic integration as an exogenous decrease in such restrictions.

\subsection{Political integration}

We consider an increase in the size of the political union. In order to determine the effect of political integration on economic growth, we must recognize that there are two separate effects on growth. First consider the growth schedule (equation 21). An increase in $m_{p}$ has the direct effect of increasing growth for any given number of regional firms, $n$. The increase in foreign competition in the political market makes rent seeking less profitable for a given number of regional firms as in the symmetric equilibrium rents are unaltered, but the amount of labour devoted to rent seeking is increased. In general equilibrium this reduces the slack provided by rent seeking and makes $R \& D$ relatively more attractive than rent

15. The logic of our results would not change if we allow foreign rent seekers to be active in the home political market provided that they face higher costs of influencing the home government (for instance, due to worse connections with home politicians). In particular, we can have firms participating in a rent seeking game in each region with the rent seeking function taking the form

$$
Q_{i k}^{l}=\left[\frac{\left(1-\beta^{l}\right) L_{Q_{i k}}^{v}}{\sum_{j=1}^{n_{k}} L_{Q_{j k}}^{v}+\sum_{s \neq k}^{m_{p}} \sum_{j=1}^{n_{s}}\left[\left(1-\beta^{l}\right) L_{Q_{j s}}\right]^{v}}\right],
$$

where $\beta^{l}=0$ for $l=k$ and $\beta^{l}=\beta>0$ for $l \neq k$. Under this specification, political integration can be seen as a decrease in the cost of rent seeking in other regions (i.e. a decrease in $\beta$ ). It can be shown that a decrease in $\beta$ has qualitatively the same effects as an increase in $m_{p}$. 


\section{Forthcoming in the Journal of the European Economic Association}

seeking, resulting in an increase in innovative activity and growth.

A second effect on growth takes place through the endogenously determined market structure. The increase in foreign competition in the political market makes rent seeking more competitive and reduces profits from the political market. With no direct effect on the economic market, some firms must exit because they are not making enough to cover the fixed and sunk cost of operating. Increased foreign political competition drives out some regional firms. To see what happens to the number of firms in the political market, rewrite the zero profit condition as a function of $M_{p}$,

$$
\frac{m_{p} L[1-T]\left[1-\theta\left(\xi\left(\frac{m_{e} M_{p}}{m_{p}}\right)-1\right)\right]}{M_{p} \xi\left(\frac{m_{e} M_{p}}{m_{p}}\right)}+\frac{\rho}{\alpha\left(\frac{m_{e} M_{p}}{m_{p}}\right)}+\frac{m_{p} L T\left[1-v\left(1-\mathscr{S}^{p}\left(M_{p}\right)\right)\right]}{M_{p}}=\varphi .
$$

Political integration (an increase in $m_{p}$ ) increases the left-hand side directly and by decreasing the elasticity of demand. In order for the condition to continue to hold, $M_{p}$ must increase. In other words, the number of firms vying for rents under political integration is larger than the number of firms in the political market before integration. This is true even though an increase in $m_{p}$ drives some domestic firms out of business.

In the economic market, with no change in $m_{e}$, it must be the case that $M_{e}$ falls. As firms drop out of the market, $R \& D$ effort is reduced because competition for market share is reduced. This results in a movement down along the growth schedule.

Political integration has an ambiguous effect on economic growth. On the one hand, it makes rent seeking less attractive relative to $R \& D$ and boosts growth. On the other hand, greater foreign competition drives out some regional producers and dissuades growth generating R\&D. This can be seen in Figure 3, where political integration implies an outward shift of the growth schedule (from $g$ to $g^{\prime}$ ) and a reduction in the regional number of firms (from $n$ to $n^{\prime}$ ). The overall effect on growth is ambiguous.

[FIGURE 3 APPROXIMATELY HERE]

A similar intuition holds for welfare. Holding constant the number of regional firms, political integration raises welfare by increasing growth. However, because tougher political competition drives out some domestic producers, the variety of consumption goods falls. This has a direct negative effect on welfare and a further negative effect through reduced growth.

Proposition 1. Political integration reduces the number of regional firms $(n)$ and the number of firms competing in the economic market $\left(M_{e}\right)$; increases the number of firms competing in the political market $\left(M_{p}\right)$; and has an ambiguous effect on innovation, economic growth and welfare. 


\section{Forthcoming in the Journal of the European Economic Association}

Brou and Ruta Economic integration, political integration or both?

Although the current specification does not allow us to be precise about the conditions under which political integration will be good for growth and welfare, some further discussion is warranted. Political integration will be positive when the direct effect (the upward shift in the growth schedule) is large and the indirect effect (the movement down along the growth schedule from a fall in $n$ ) is small. Inspection of equations (21) and (20) reveals that this will occur when $v$ is small relative to $\varepsilon$ and $\theta .{ }^{16}$ Political integration will be beneficial when economic markets are inherently more competitive than political markets because the gain from increased competition in the political market (by making rent seeking less attractive relative to $\mathrm{R} \& \mathrm{D}$ ) will more than offset the loss of some firms.

\subsection{Economic integration}

We now turn our attention to the effects of economic integration. As with political integration, there is a direct effect on growth and an indirect effect through the market structure. Inspection of equation (21) reveals that an increase in $m_{e}$ has the direct effect of increasing growth for any given number of regional firms, $n$. The increase in foreign economic competition means that firms face tougher price competition and benefit from greater technological spillovers, inducing them to raise $\mathrm{R} \& \mathrm{D}$ effort and, consequently, growth. At the same time, lower prices and greater $R \& D$ expenditures mean that some existing firms will have to exit the market in order to satisfy the zero profit condition (20). We can show that the number of firms competing in the economic market increases by rewriting the zero profit condition in terms of $M_{e}$ :

$\frac{m_{e} L[1-T]\left[1-\theta\left(\xi\left(M_{e}\right)-1\right)\right]}{M_{e} \xi\left(M_{e}\right)}+\frac{\rho}{\alpha\left(M_{e}\right)}+\frac{m_{e} L T\left[1-v\left(1-\mathscr{S}^{p}\left(\frac{m_{p} M_{e}}{m_{e}}\right)\right)\right]}{M_{e}}=\varphi$.

Economic integration (an increase in $m_{e}$ ) increases the left-hand side directly and by increasing $\mathscr{S}^{p}$. In order for the condition to continue to hold, $M_{e}$ must increase. The number of firms in an enlarged economic union is greater even though some domestic producers close down. In the political market, the departure of regional firms with no change in $m_{p}$ diminishes competition for rents and makes rent seeking more profitable.

The effect of economic integration on growth is ambiguous in this model. For a given number of domestic firms, the growth rate is always higher under increased economic integration, because the price elasticity of demand, $\xi$, is larger. At the same time, exposure to more technological spillovers makes innovation

16. The shift in the growth schedule is determined by $\partial g / \partial m_{p}=$ $\left[\theta^{2}(\xi-1) /(1-\theta(\xi-1))\right]\left[v L T /\left(m_{p} n\right)^{2}\right]$. The decrease in $n$ is a response to the decrease in the left-hand side of equation (20), $\partial L H S / \partial m_{p}=-\left[v L T /\left(m_{p} n\right)^{2}\right]$. 


\section{Forthcoming in the Journal of the European Economic Association}

'cheaper'. Foreign competition decreases the economic market power of each firm making R\&D more attractive and causing growth to rise. However, the change in market structure and the increase in rent seeking activities negatively affect the economic performance of countries in the long run. The interaction of these political and economic effects determines the rate of growth of the economy. In terms of Figure 4, the growth schedule shifts up and the vertical line representing the equilibrium number of firms shifts to the left.

[FIGURE 4 APPROXIMATELY HERE]

In terms of welfare, consumers benefit from the increase in variety of consumption goods. The ambiguous changes in innovation and growth, however, preclude a clear effect of economic integration on welfare.

PROPOSITION 2. Economic integration reduces the number of regional firms ( $n$ ) and the number of firms competing in the political market $\left(M_{p}\right)$; increases the number of firms competing in the economic market $\left(M_{e}\right)$; and has an ambiguous effect on innovation, economic growth and welfare.

A move toward economic integration will cause the number of firms operating in each region to fall even as the global number of goods available to consumers increase. This is the homogenization effect of trade liberalization. We argue that this elimination of domestic firms can be particularly damaging because it makes rent seeking a much more appealing proposition for the remaining domestic firms. Opening the market to trade increases economic competition and results in greater price competition which requires greater $R \& D$ expenditures. But as domestic firms drop out of the market, political power is concentrated and rent seeking becomes more attractive. Firms that were once protected by trade restrictions turn their efforts to influence their government to obtain different forms of favors once these restrictions are no longer in place (public transfers are likely to be good substitutes for trade barriers from the firm's perspective). This draws resources away from $R \& D$. The overall effect of economic integration on $R \& D$ (and therefore growth) is ambiguous.

\subsection{Economic and political integration}

We now turn our attention to the interaction between economic and political integration. Consider economic integration (however the same argument can be made using political integration as the starting point). On impact, economic integration shifts the growth schedule by

$$
\partial g / \partial m_{e}=\left(\partial \xi / \partial m_{e}\right)\left(\theta^{2}\left(\varphi-\Pi^{p}\right)-\rho\right) /[1-\theta(\xi-1)]^{2}>0 .
$$

As discussed above, this is a result of increased competition over market share for any given level of $n$. The level of political integration plays an important role in 


\section{Forthcoming in the Journal of the European Economic Association}

the size of this effect because it determines the slack afforded to firms by political profits. More formally, we can see that the shift in the growth schedule is greater when there is more political integration by taking the derivative with respect to $m_{p}: \partial g^{2} / \partial m_{e} \partial m_{p}>0$.

It is important to also note that the level of political integration does not affect the decrease in $n$. Recall that the change in $n$ is determined by the size of the shift in the left-hand side (LHS) of the zero-profit condition (20):

$$
\partial L H S / \partial m_{e}=-\left[L(1-T)(1+\theta) /(n \xi)^{2}\right]-\left[(\rho / \alpha) \partial \alpha / \partial m_{e}\right]<0 .
$$

This effect is independent of $m_{p}$ (i.e. $\partial L H S^{2} / \partial m_{e} \partial m_{p}=0$ ). Since the shift in the growth schedule caused by economic integration is greater under higher levels of political integration and the change in $n$ the same, it must be the case that the growth effect of economic integration will be greater when there is greater political integration.

In order to consider the effects of joint economic and political integration on the total number of firms, we will focus on an economy with $m_{e}=m_{p}=m \cdot{ }^{17}$ Joint economic and political integration can then be analyzed as an increase in $m$. An increase in $m$ reduces total profits for any given value of $n$ by increasing competition in both the economic and political markets. Both activities become less profitable and some regional firms must exit the market. Expressing the zero profit condition as a function of the global number of firms $M \equiv m n$ yields

$$
\frac{m L[1-T][1-\theta(\xi(M)-1)]}{M \xi(M)}+\frac{\rho}{\alpha(M)}+\frac{m L T\left[1-v\left(1-\mathscr{S}^{p}(M)\right)\right]}{M}=\varphi .
$$

An increase in $m$ increases the left-hand side for any given value of $M$ so the global number of firms increases even though some firms in each region exit the market.

Lastly, consider the effect of full integration on welfare. As an increase in the size of an economic and political union increases the number of firms in both the economic and political markets and has a stronger effect on growth than economic or political integration alone, it must be that welfare improves under a full integration strategy compared to partial integration.

Proposition 3. Full integration reduces the number of regional firms $(n)$; increases the number of firms competing in the economic and political markets $\left(M_{e}\right.$ and $\left.M_{p}\right)$; and results in better outcomes for innovation, growth and welfare than either economic or political integration alone.

17. This approach is for expositional convenience only. 


\section{Forthcoming in the Journal of the European Economic Association}

As mentioned in the previous Section, economic integration alone does not guarantee improvements in growth and welfare because it increases the attractiveness of rent seeking relative to R\&D. Political integration, by increasing competition in the political market, offsets this mechanism. In this sense, political and economic integration can be seen as complementary.

Let us stress that the problem with economic integration on its own is that it increases competition in the economic market and not in the political market. This skews firms' incentives toward rent seeking. Political integration is one way to solve this problem because it introduces an equiproportional increase in political competition. This ensures that the benefits of increased economic competition are fully realized. In practice, it should be noted that other effects of free trade might also be in place, even if not explicitly modeled in this paper. Economic integration is generally perceived as beneficial to the quality of institutions. ${ }^{18}$ If this is the case, trade could be associated with creating inherently more competitive political markets as well (an increase in $v$ ). As long as economic integration is carried out in a way that does not make firms want to focus on rent seeking, the benefits of open trade will be realized. However, due to the complementarity of economic and political integration, these benefits will be larger under a full integration strategy.

We take a moment to discuss the generality and robustness of our results. A number of recent studies in international trade (see, for instance, Ottaviano et al. 2002, and Melitz and Ottaviano, 2008) assume a linear demand function rather than the CES formulation adopted in this model. While this alternative formalization is more suitable to study variable mark-ups in an environment characterized by a large number of firms, we prefer the current formulation which is more easily treatable and allows for a closed form solution. ${ }^{19}$ We are confident that these modeling choices do not drive the main results. Essentially, our findings rely on the following characteristics of the economic part of the model: (i) that profits from the economic market $\left(\Pi_{e}\right)$ are decreasing in the number of firms $\left(M_{e}\right)$; (ii) that economic integration (an increase in me) affects profits both directly and through the number of firms (i.e. that we can write $\Pi_{e}\left(m_{e}, M_{e}\right)$ ); and (iii) that there is a positive relationship between growth $(g)$ and the number of regional firms $(n)$. The first characteristic is common in linear demand trade models (the "pro-competitive effect") as is the second. The final characteristic is difficult to establish in relation to the linear demand model. However, Cellini and Lamber-

18. Empirical evidence suggests that more open economies tend to be associated with better institutions (see Rodrik, Subramanian and Trebbi, 2004). However, the causal relationship is not obvious.

19. Cellini (2000) argues that assuming a linear demand in this framework would also be problematic as a linear formulation of market demand is inconsistent with any reasonable form of balanced growth. This implies that the focus of a model with these characteristics has to be on convergence to a steady state rather than endogenous growth. 


\section{Forthcoming in the Journal of the European Economic Association}

tini (2004) show that there is a positive relationship between the number/mass of firms and R\&D investment along the equilibrium path in a model with linear demand.

\section{Conclusions}

This paper presents an endogenous growth model with rent seeking and studies the economic effects of political and economic integration. Contrary to the previous literature which treats political integration as an alternate way of increasing the size of the economic market, we find that economic and political integration can function as complementary institutions. When firms engage in both innovation and unproductive rent seeking, changes in the economic and political markets alter the benefits of each type of activity. By considering political integration as an increase in the size of the political market - and independent of the size of the economic market - we see that it has an ambiguous effect on innovation, growth and welfare. The results for economic integration on its own are similar. It increases competition for market share, which tends to increase a firm's incentive to innovate. But it also eliminates some of the regional firms, reducing competition and making rent seeking more attractive for the remaining firms. The overall effect on innovation, growth and welfare is ambiguous. Whether political or economic integration alone increase growth and welfare will depend on the relative level of competition in each market. Joint integration makes both the political and economic markets more competitive without altering the incentives across these markets. Innovation becomes more attractive and growth and welfare increase.

Our conclusions are in line with other arguments that have recently emerged in the literature on globalization and political structure. First, the view that integrated economic markets need political as well as legal and social institutions for their effective functioning (see Rodrik, 2000, and Wolf, 2004). Second, the view that the proliferation of borders reduces trade (and, therefore, growth) even when countries share culture, language and institutions (McCallum, 1995). And third the view that globalization is creating new policy externalities and this leads national governments to choose worse economic policies (Broner and Ventura, 2009, and Epifani and Ganica, 2009, among others).

Although, as discussed in the introduction, the work of Alesina, Spolaore and Wacziarg (2000) has markedly different results from our model (namely that economic integration should be accompanied by political disintegration), the two works should be seen as complementary. Governments engage in a multiplicity of activities. In some of these activities (e.g. education, cultural policy) heterogeneity of policy preferences may be extremely relevant. In other policy areas (e.g. subsidies, market regulation) rent seeking might be pervasive. The focus of Alesina, Spolaore and Wacziarg (2000) is on the first type of activities, while this 


\section{Forthcoming in the Journal of the European Economic Association}

paper emphasizes the latter. Taken together, the two articles suggest that globalization should be associated with a change in the global political structure, and provide some insights on the direction such a change should take.

There are, of course, some important caveats to our results. The issue of political integration is clearly a complex one and requires more theoretical and empirical work. To address it in a formal and tractable model, we focus on a highly stylized representation of the political market. It would be quite optimistic to argue that this fully captures the implications of political integration. The goal of this paper is to isolate the competition effects from the point of view of the firms whose R\&D investments drive economic growth. We abstract away from clearly important considerations such as changes in the quality and structure of institutions, government incentives and the loss of sovereignty.

Another possible concern is that firms' unproductive activity can take other forms. If firms lobby for anti-competitive policies such as extensions of patents rights or barriers to entry, there may be a positive effect on innovation and growth since these policies increase the return to innovation. While this is a theoretical possibility, the empirical relationship between competition and innovation is positive or inverted U-shaped (see the discussion in the introduction). There is no guarantee that successfully lobbying for this type of policy change will result in an increase in $R \& D$ effort. Furthermore, if firms have to allocate resources to obtaining these policies, this will still draw resources away from innovative activity. In our model in particular, any labor dedicated to lobbying cannot be used for $R \& D$.

To draw policy implications from a stylized model such as this one is difficult, but tempting. We briefly discuss some possible applications. First, most of the recent political break ups, from the USSR to Montenegro, took place in countries where the quality of institutions were low. Political disintegration in the former Soviet Union in particular has been accompanied by an astonishing increase in rent seeking activities and a large fall in growth rates. The two are obviously related to the collapse of the socialist system of production and the transition to a market economy. However, it is tempting to argue that the political break up per se had effects on both rent seeking and growth as predicted by this model. Local oligarchs found much less competition in their local polities and focused their efforts on unproductive methods of obtaining income.

Our results also have implications for sovereigntist movements. A common argument is that, in a world of trade agreements, the economic costs of political independence are low (one example is that of Quebec nationalists and the North American Free Trade Agreement.) Our model suggests that this argument fails to realize that a political break up itself might have effects on economic growth and that these effects are magnified (not lowered) by economic integration.

Finally, economic integration in Europe has been accompanied by some degree of political integration. After the creation of the European Communities 


\section{Forthcoming in the Journal of the European Economic Association}

Brou and Ruta Economic integration, political integration or both?

(later called the European Union) in the 1950s, countries that preferred economic integration with no political integration formed three other free trade areas, the most important being the European Free Trade Association (EFTA). However, most of its initial signatories later opted to join the EU and ceased to be EFTA members. The recent integration of Eastern and Central European countries in the European Union represents another example of countries preferring joint economic and political integration over a purely economic integration strategy. Currently the EU has exclusive competence in several policy areas, namely those concerning the regulation of the internal market. Of particular interest is the discipline of state aid to firms (that closely resemble the kind of transfers in our model). National governments have been limited by the Treaties in their ability to decide such policy and the European Commission has been empowered with enforcement. In both cases (regulation of the internal market and state aid), we argue that an underlying reason is to prevent firms from avoiding economic competition by focusing their efforts on local (i.e. national) rent seeking activities that would undermine the benefits of establishing a single market in Europe.

\section{References}

[1] Aghion, Philippe, Nicholas Bloom, Richard Blundell, Rachel Griffith, and Peter Howitt (2005). "Competition and Innovation: An Inverted-U Relationship." Quarterly Journal of Economics, 120, 701-728.

[2] Aghion, Philippe and Peter Howitt (1998). Endogenous Growth Theory, The MIT Press.

[3] Alesina, Alberto and Enrico Spolaore (2003). The Size of Nations, The MIT Press.

[4] Alesina, Alberto, Enrico Spolaore, and Romain Wacziarg (2000). "Economic Integration and Political Disintegration." American Economic Review, 90, 1276-1296.

[5] Alesina, Alberto, Enrico Spolaore, and Romain Wacziarg (2005). "Trade, Growth and the Size of Countries." In Handbook of Economic Growth, edited by Philippe Aghion and Steven Durlauf. North Holland.

[6] Bhagwati, Jagdish (1982). "Directly Unproductive, Profit-Seeking (DUP) Activities." Journal of Political Economy, 90, 988-1002.

[7] Baumol, William J. (1990). "Entrepreneurship: Productive, Unproductive and Destructive." Journal of Political Economy, 98, 893-921.

[8] Baye, Michael R., Dan Kovenock, and Casper G. deVries (1999). "The Incidence of Overdissipation in Rent-Seeking Contests." Public Choice, 99, 439-454.

[9] Becker, Gary S. (1983). "A Theory of Competition among Pressure Groups for Political Influence." Quarterly Journal of Economics, 101, 371-400. 


\section{Forthcoming in the Journal of the European Economic Association}

Brou and Ruta Economic integration, political integration or both?

[10] Bliss, Christopher and Rafael Di Tella (1997). "Does Competition Kill Corruption.” Journal of Political Economy, 105, 1001-1023.

[11] Blundell, Richard, Rachel Griffith, and John Van Reenen (1999). "Market Share, Market Value and Innovation in a Panel of British Manufacturing Firms." Review of Economic Studies, 66, 529-554.

[12] Broner, Fernando and Jaume Ventura (2009). "Globalization and Risk Sharing." Mimeo, CREI and Universitat Pompeu Fabra.

[13] Brou, Daniel and Michele Ruta (2008). "Rent Seeking, Market Structure and Growth." Mimeo, University of Western Ontario and World Trade Organization.

[14] Buchanan, James M. (1990). "An American Perspective on Europe's Constitutional Opportunity." Cato Journal, 10, 619-630.

[15] Cellini, Roberto (2000). "Growth and Differentiated Oligopoly." Economic Letters, 69, 129-136.

[16] Cellini, Roberto and Luca Lambertini (2004). "R\&D Incentives Under Bertrand Competition: A Differential Game." Mimeo, Universita di Bologna.

[17] Coe, David T. and Elhanan Helpman (1995). "International R\&D Spillovers." European Economic Review, 39, 859-887.

[18] Epifani, Paolo and Gino Ganica (2009). "Openness, Government Size and the Terms of Trade." Review of Economic Studies, 76, 629-668.

[19] Gawande, Kishore, Pravin Krishna, and Michael J. Robbins (2004). "Foreign Lobbies and US Trade Policy." The Review of Economics and Statistics, $88,563-571$.

[20] Grossman, Gene M. and Elhanan Helpman (1991). Innovation and Growth in the Global Economy, The MIT Press.

[21] Lumenga-Neso, Olivier, Marcelo Olarreaga, and Maurice Schiff (2005). "On 'Indirect' Trade-Related R\&D Spillovers." European Economic Review, 49, 1785-1798.

[22] Madison, James (1788) The Federalist Papers, No.10 New York.

[23] Hume, David (1987). "Idea of A Perfect Commonwealth." In Essays, Moral, Political and Literary, edited by Eugene F. Miller, Liberty Fund, Inc.

[24] McCallum, John (1995). "National Borders Matter: Canada-U.S. Regional Trade Patterns." American Economic Review, 85, 615-623.

[25] Melitz, Marc J. and Gianmarco I.P. Ottaviano (2008) Review of Economic Studies, 75, 295-316.

[26] Murphy, Kevin M., Andrei Shleifer, and Robert W. Vishny (1991). "The Allocation of Talent: Implications for Growth." Quarterly Journal of Economics, 106, 503-530.

[27] Nickell, Stephen J. (1996). "Competition and Corporate Performance." Journal of Political Economy, 104, 724-746. 


\section{Forthcoming in the Journal of the European Economic Association}

Brou and Ruta Economic integration, political integration or both?

[28] Olson, Mancur (1982). The Rise and Decline of Nations, Yale University Press.

[29] Ottaviano, Gianmarco, Takatoshi Tabuchi, and Jacques-Francois Thisse (2002) "Agglomeration and Trade Revisited." International Economic Review, 43, 409-435.

[30] Peretto, Pietro F. (1996). "Sunk Costs, Market Structure and Growth." International Economic Review, 37, 895-923.

[31] Peretto, Pietro F. (2003). "Endogenous Market Structure and the Growth and Welfare Effects of Economic Integration." Journal of International Economics, 60, 177-201.

[32] Persson, Torsten, Guido Tabellini, and Francesco Trebbi (2003). "Electoral Rules and Corruption." Journal of the European Economic Association, 1, 958-989.

[33] Rodrik, Dani (2000). "How Far Will International Economic Integration Go?." Journal of Economic Perspectives, 14, 177-186.

[34] Rodrik, Dani, Arvind Subramanian, and Francesco Trebbi (2004). "Institutions Rule: The Primacy of Institutions Over Geography and Integration in Economic Development." Journal of Economic Growth, 9, 131-165.

[35] Ruta, Michele (2005). "Economic Theories of Political (Dis)integration." Journal of Economic Surveys, 19, 1-21.

[36] Spinelli, Altiero (1957). Manifesto dei Federalisti Europei, Guanda Editore.

[37] Spolaore, Enrico and Romain Wacziarg (2005). "Borders and Growth." Journal of Economic Growth, 10, 331-386.

[38] Tullock, Gordon (1980). "Efficient Rent Seeking." In Toward a Theory of the Rent Seeking Society, edited by J.M. Buchanan, R. D. Tollison and G. Tullock, Texas A\&M Press.

[39] Wolf, Martin (2004). "One Economy, Many States: The Political Economy of Globalization." Thirteenth Annual IEA Hayek Memorial Lecture, Institute of Economic Affairs. 
Forthcoming in the Journal of the European Economic Association

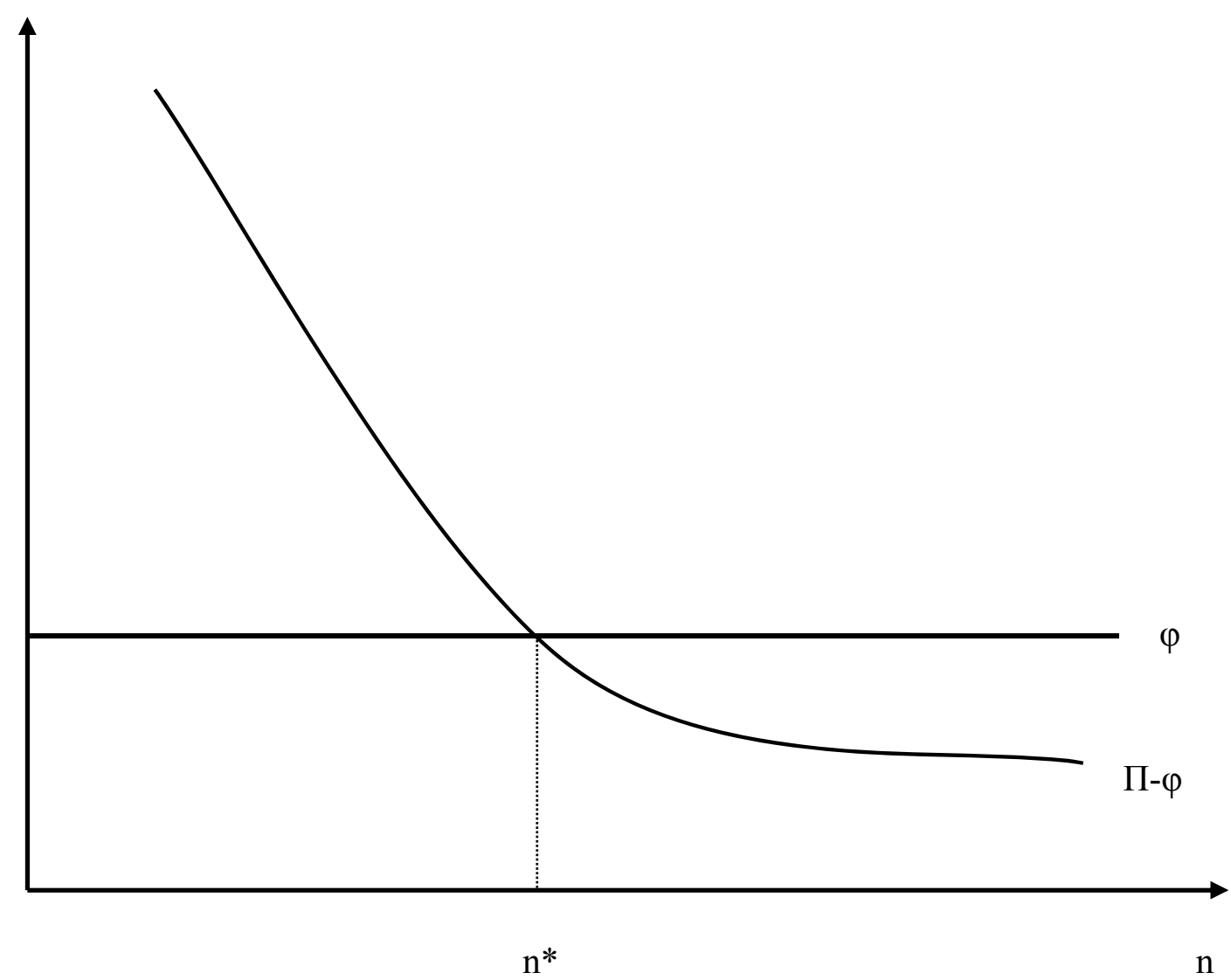

Figure 1: Equilibrium market structure 
Forthcoming in the Journal of the European Economic Association

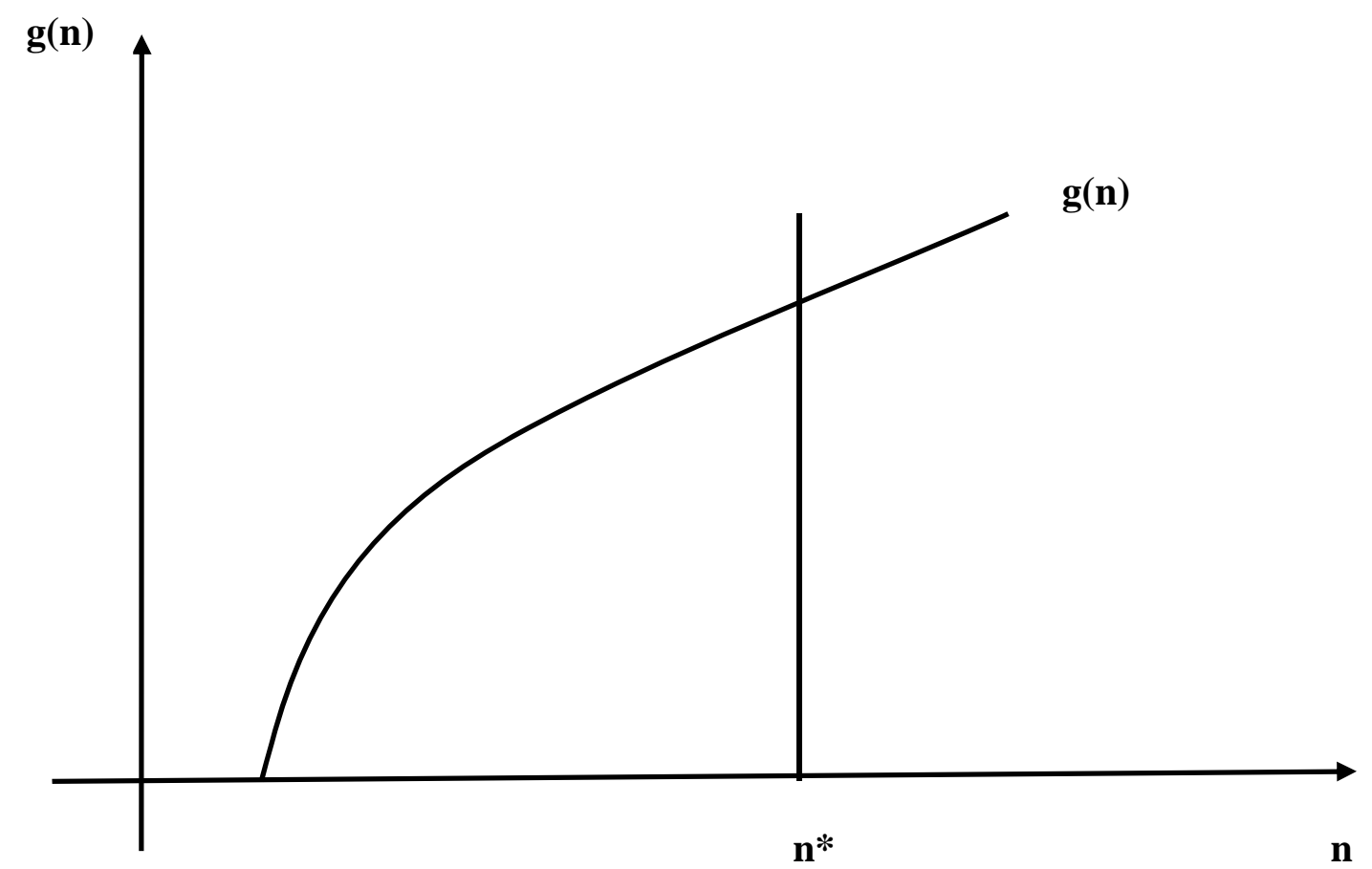

Figure 2: Equilibrium growth 
Forthcoming in the Journal of the European Economic Association

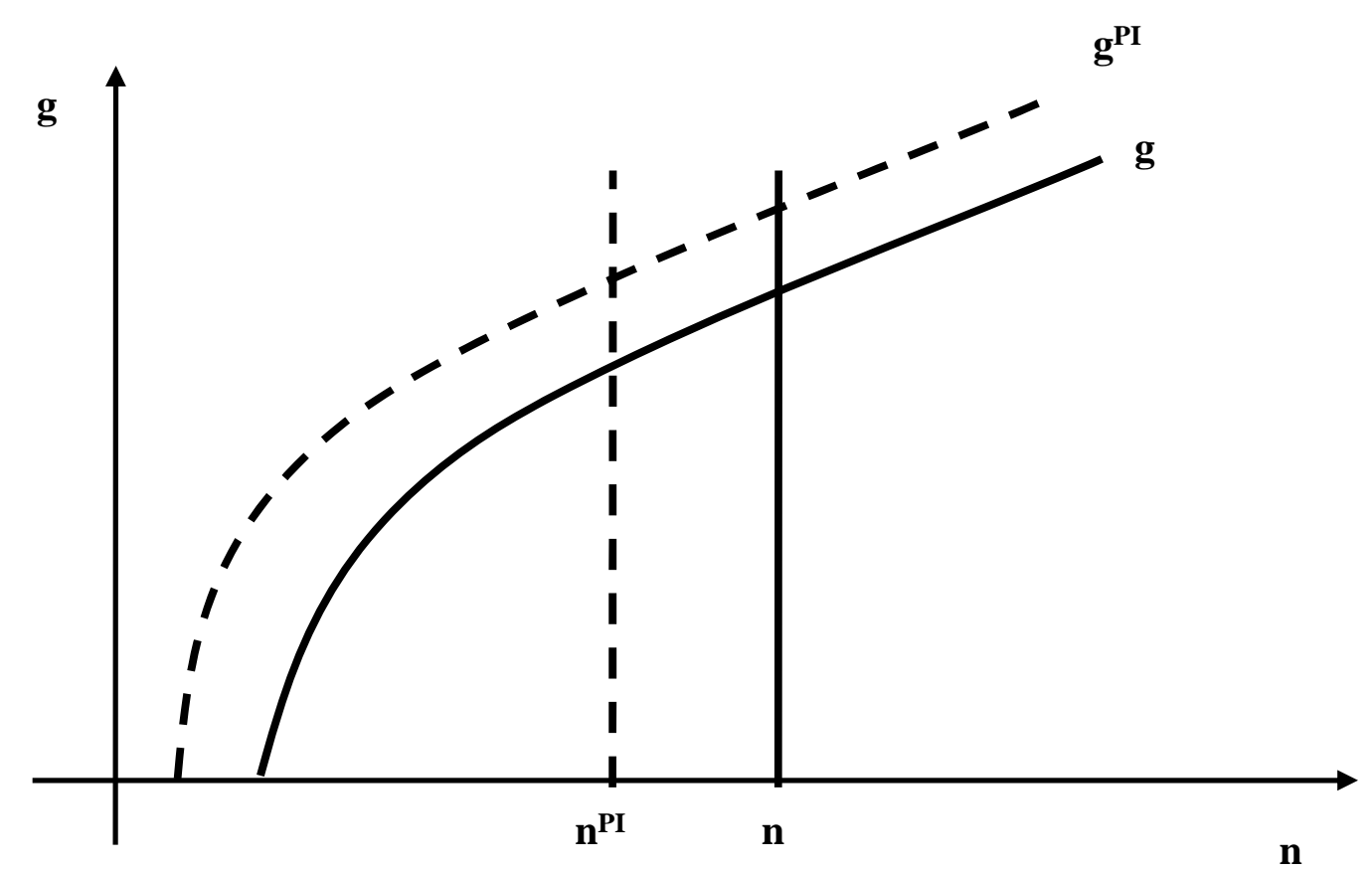

Figure 3: The effects of political integration 
Forthcoming in the Journal of the European Economic Association

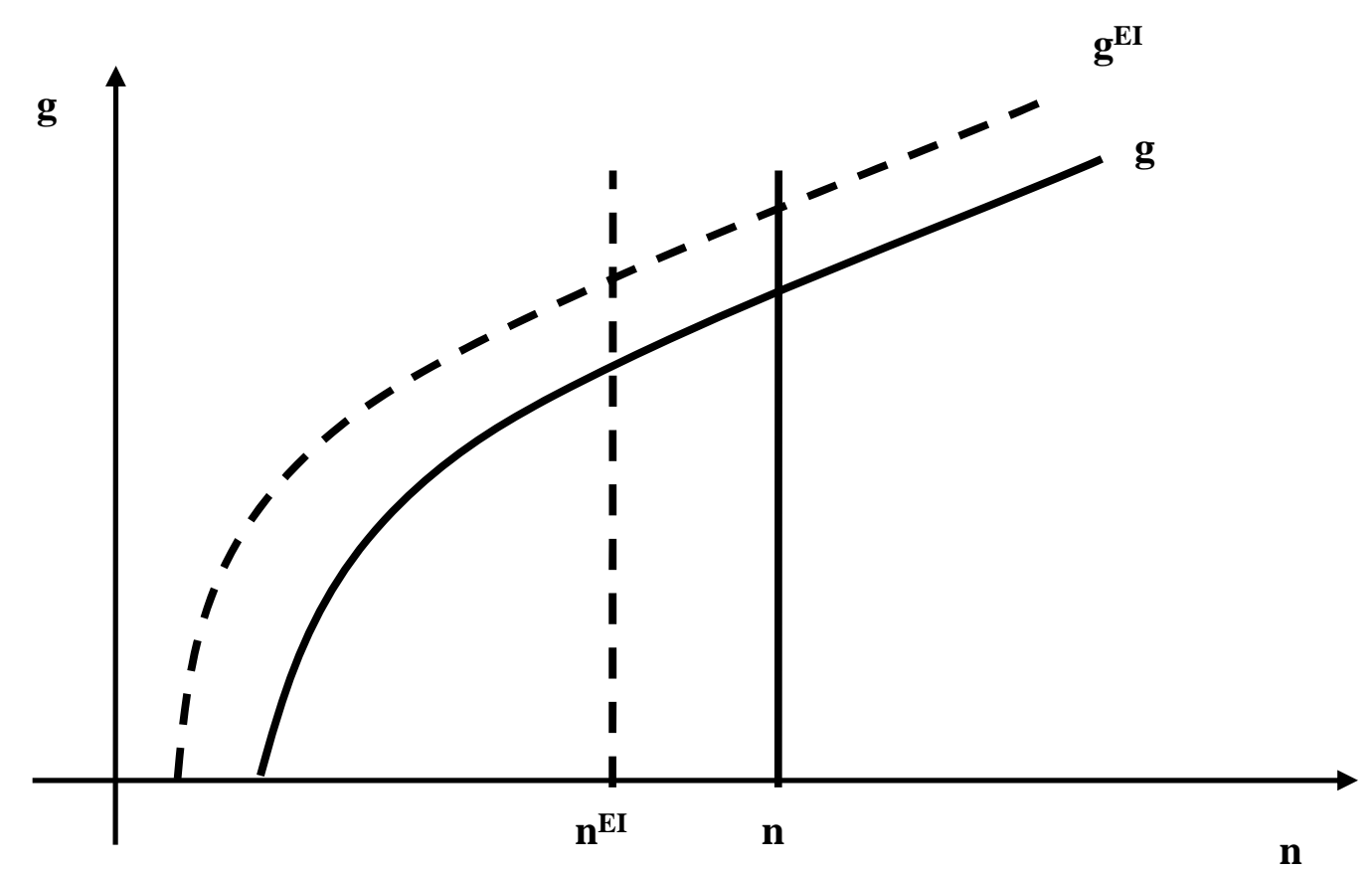

Figure 4: The effects of economic integration 